\title{
OPTIMASI HPMC DAN KARBOPOL DALAM FORMULASI SEDIAAN GEL ANTISEPTIK EKSTRAK DAUN BELUNTAS (Pluchea indica L.) DAN AKTIVITAS TERHADAP Staphylococcus aureus
}

\author{
Muhammad Dienulloh Qasyfur Rohman", Iwan Setiawan, Ardy Prian Nirwana \\ Fakultas Farmasi, Stikes Nasional 664830, Indonesia \\ *: qr1dino@gmail.com
}

\begin{abstract}
Abstrak
Daun Beluntas ( Pluchea indica, L.) merupakan salah satu tanaman yang mempunyai potensi sebagai antibakteri, Dimana pada daun beluntas memiliki beberapa kandungan senyawa salah satunya yaitu senyawa flavonoid yang mempunyai aktivitas antibakteri. Tujuan penelitian ini untuk mengetahui komposisi yang optimum dari basis HPMC dan Karbopol yang akan diformulasikan dalam sediaan gel antiseptik ekstrak etanol daun beluntas dengan menggunkan metode simplex lattice design. Metode ekstraksi yang digunakan dalam penelitian ini yaitu menggunakan metode Maserasi dengan pelarut etanol. Pembuatan sediaan gel antiseptik dilakukan dengan mengoptimasi basis HPMC dan Karbopol, kemudian dilakukan pengujian kontrol kualitas sediaan gel dan didapatkan hasil yang memenuhi persyaratan pada homogenitas, $\mathrm{pH}$, daya sebar, viskositas, konsistensi dan uji stabilitas sediaan gel. Formula optimum gel antiseptik berdasarkan metode simplex lattice design yaitu pada kombinasi basis HPMC 4,5\% dan Karbopol 0,5\%. Pengujian aktivitas antibakteri didapatkan zona hambat, hal ini menunjukkan bahwa sediaan gel antiseptik ekstrak etanol daun beluntas mempunyai kemampuan penghambatan terhadap bakteri Staphylococcus aureus dengan rata-rata diameter zona hambat sebesar 17, $66 \mathrm{~mm}$.
\end{abstract}

Kata kunci: Daun Beluntas, gel antiseptik, Staphylococcus aureus

\begin{abstract}
Beluntas leaf (Pluchea indica, L.) is one of the plants that has potential as an antibacterial, Where the leaves of Beluntas have several compounds, one of these is a flavonoid which has antibacterial activity. The aim of this research is to determine the optimum composition of HPMC and carbopol which will be formulated in the preparation of antiseptic gel ethanol extract of beluntas leaf using the simplex lattice design method. The extraction method used in this study is Maseration with ethanol as a solvent. Antiseptic gel manufacturing is done by optimizing the base of HPMC and Carbopol, Then testing the quality of the gel preparation and the results obtained that meet the requirements of the homogeneity, $\mathrm{pH}$, dispersion, viscosity, consistency and stability test of the gel preparation. The optimum formula of antiseptic gel based on the simplex lattice design method is on a combination of a $4.5 \%$ HPMC base and a $0.5 \%$ carbopol. Antibacterial activity test found inhibition zone, this shows that the antiseptic gel preparation of the ethanol extract of beluntas leaves has the ability to inhibit against Staphylococcus aureus bacteria with an average diameter of the zone of inhibition by 17,66 $\mathrm{mm}$.
\end{abstract}

Keywords: Beluntas leaves, antiseptic gel, Staphylococcus aureus 
Jurnal Insan Farmasi Indonesia, 3(2) Desember 2020 (327-336)

Muhammad Dienulloh Qasyfur Rohman

p-ISSN 2621-3184 ; e-ISSN 2621-4032

doi: $10.36387 /$ jifi.v3i2.566

\section{PENDAHULUAN}

Sediaan antiseptik merupakan suatu zat yang telah banyak digunakan untuk menghambat pertumbuhan dan membunuh mikroorganisme yang ada disekitar permukaan tubuh khususnya pada telapak tangan yang sering mengalami kontak dengan permukaan suatu benda. Selain itu, pada antiseptik mempunyai mekanisme kerja yaitu, merusak lemak yang ada didalam membran sel bakteri ataupun dengan cara menghambat salah satu kerja dari enzim yang ada pada bakteri, dimana enzim pada bakteri berfungsi untuk biosentesis asam lemak $^{(1)}$

Pada saat ini telah mulai dikembangkan penggunaan obatobatan yang berasal dari bahan alam yang aman dan mempunyai efek samping yang tidak berbahaya, Salah satunya pada penggunaan daun beluntas (Pluchea Indica L.) sebagai antibakteri. berdasarkan penelitian yang dilakukan oleh Rompas ${ }^{(4)}$ mengatakan bahwa ekstrak etanol daun beluntas mempunyai aktivitas penghambatan terhadap bakteri
Staphylococcus aureus, E.coli, Pseudomonas fluorecens, dan Salmonela typhi.

HPMC dan Karbopol merupakan basis yang sering digunakan dalam pembuatan sediaan gel. Salah satu metode optimasi yang sering digunakan untuk mendapatkan formula yang optimum adalah metode Simplex Lattice Design, dimana metode ini dapat membantu dalam menentukan formula yang optimum pada suatu sediaan.

Berdasarkan latar belakang di atas peneliti tertarik untuk mengetahui konsentrasi yang optimum pada gelling agent HPMC dan Karbopol yang akan diformulasikan dalam bentuk sediaan gel antiseptik ekstrak etanol daun beluntas (Pluchea indica L.).

\section{METODE}

Bahan.

Natrium klorida $(\mathrm{NaCl})$ 0,9\%, HPMC, Karbopol, TEA, Gliserin, natrium metabisulfit, Amil alkohol, Serbuk magnesium, asam klorida $2 \mathrm{~N}$, media MHA, MSA, BHI, Antibiotik 
Jurnal Insan Farmasi Indonesia, 3(2) Desember 2020 (327-336)

Muhammad Dienulloh Qasyfur Rohman

p-ISSN 2621-3184 ; e-ISSN 2621-4032

doi: 10.36387/jifi.v3i2.566

ciprofloxacin, bakteri Staphylococcus

antara campuran pertama dan aureus.

\section{Pengolahan Sampel}

Daun beluntas dipisahkan dari tangkai, batang dan akarnya. Selanjutnya dibersihkan dari sisa-sisa tanah, kotoran dan dicuci dengan air yang bersih dan mengalir. Selanjutnya dikeringkan dan diayak dengan ayakan mesh no. 30 .

\section{Ekstraksi Sampel}

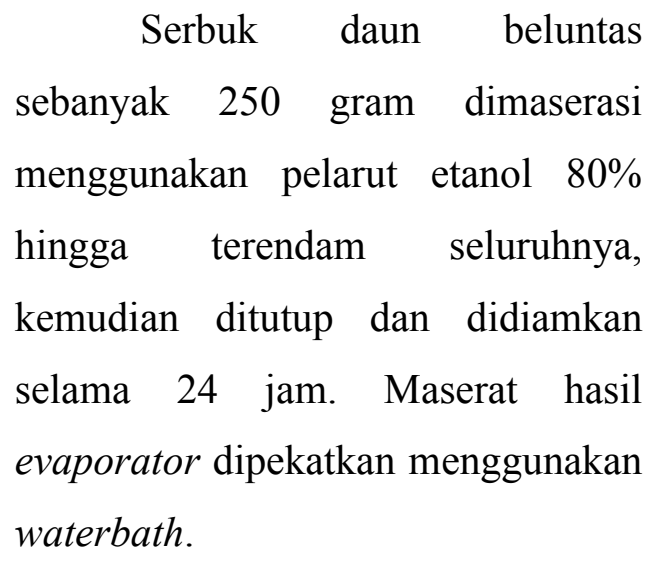

\section{Pembuatan sediaan gel antiseptik}

Basis (HPMC dan Karbopol) dikembangkan terlebih dahulu dengan akuades panas (Bagian pertama), Natrium metabisulfit dilarutkan dalam sebagian gliserin. Setelah itu, ditambahkan Ekstrak daun beluntas dan TEA, selanjutnya ditambahkan sisa gliserin dan diaduk hingga homogen (Bagian kedua). Selanjutnya dilakukan pencampuran campuran kedua, digerus hingga homogen, serta ditambahkan akuades, hingga volume yang dikhendaki.

\section{Uji sifat fisik}

\section{Uji homogenitas}

Pengujian homogenitas dilakukan dengan cara timbang sediaan gel sebanyak 0,5-1g. pengamatan tekstur sediaan gel antiseptik, standar SNI 06-2588 untuk uji homogenitas sediaan gel tidak boleh terdapat bulir maupun gumpalan saat sediaan ditindih dengan plat kaca ${ }^{(7)}$

\section{Uji pH}

stik $\mathrm{pH}$ meter dicelupkan kedalam sampel gel yang telah diencerkan. Bandingkan dengan Standar SNI 06-2588

\section{Uji daya sebar}

Sediaan ditimbang sebanyak 0,5 gram, diletakkan pada plat kaca dan ditindih menggunakan plat kaca selama 1 menit. dilakukan pengukuran diameter sediaan menggunakan jangka sorong sebanyak tiga sisi (vertical, horizontal, dan diagonal). tahap berikutnya sediaan ditindih kembali 
Jurnal Insan Farmasi Indonesia, 3(2) Desember 2020 (327-336)

Muhammad Dienulloh Qasyfur Rohman

p-ISSN 2621-3184 ; e-ISSN 2621-4032

doi: $10.36387 /$ jifi.v3i2.566

dengan beban sebesar 150 gram

Verifikasi formula optimum

selama 1 menit. Standar SNI 06-2588

Verifikasi formula optimum

untuk uji daya sebar sediaan gel berkisar antara $50-70 \mathrm{~mm}^{(7)}$

\section{Uji viskositas}

Penentuan nilai viskositas sediaan gel menggunakan viscotester seri VT 04, ${ }^{(8)}$

\section{Uji konsistensi}

sentrifus, dengan kecepatan 3000 rpm selama 5-10 menit. Standar SNI 06-2588 untuk pengujian konsistensi sediaan gel harus mempunyai konsistensi bentuk semisolid $^{(7)}$

\section{Penentuan formula optimum}

Penentuan formula optimum sediaan gel antiseptik menggunakan software design expert $11^{(9)}$

\section{Uji stabilitas sediaan gel antiseptik}

Pengujian stabilitas sediaan gel antiseptik dilakukan secara freeze thaw sebanyak 3 siklus, setiap siklusnya sediaan ditempatkan pada suhu $4^{\circ} \mathrm{C}$ dan $40^{\circ} \mathrm{C}$, selama 24 jam pada masing-masing suhu. Setiap berakhirnya 1 siklus dilakukan pengujian Homogenitas, uji $\mathrm{pH}$, uji daya sebar, uji viskositas, uji konsistensi $^{(10)}$

dilakukan untuk membandingkan antara hasil prediksi dari software design expert dengan hasil pengujian sifat fisik yang dilakukan tanpa menggunakan Software design expert.

\section{Pengujian Aktivitas Antibakteri \\ Pengecatan gram}

Biakan bakteri diberi larutan gram A,B,C dan D setelah 2 menit buang sisa cat dan dicuci pada air yang mengalir amati pada lensa obyektif $100 \mathrm{x}^{(11)}$.

\section{Identifikasi pada media MSA}

Staphylococcus

aureus kedalam media MSA secara streak plate. Setelah itu, diinkubasi pada suhu $37^{\circ} \mathrm{C}$ Selama $18-24$ jam, adanya pertumbuhan koloni bakteri Staphylococcs aureus yang ditandai perubahan warna media dari warna merah hingga kuning ${ }^{(12)}$.

\section{Uji katalase}

Koloni yang berwarna kuning diambil dari media MSA dengan menggunakan ose yang selanjutnya dicampur dengan satu tetes H2O2pada objek glass. Setelah itu 
Jurnal Insan Farmasi Indonesia, 3(2) Desember 2020 (327-336)

Muhammad Dienulloh Qasyfur Rohman

p-ISSN 2621-3184 ; e-ISSN 2621-4032

doi: $10.36387 /$ jifi.v3i2.566

dilakukan pengamatan adanya bakteri

Staphylococcus aureus ditandai

dengan munculnya gelembung gas ${ }^{(13)}$.

\section{Uji koagulase}

2-3 ohse $\mathrm{NaCl} \quad 0,9 \%$.

Kemudian ditambahkan 1 tetes

Plasma citrat. setelah itu, campur dan homogenkan Hasil dikatakan positif jika terjadi aglutinasi atau pengumpalan.

\section{Persiapan suspensi bakteri}

disuspensikan pada Nacl $0,9 \%$. Setelah itu, suspensi bakteri dibandingkan kekeruhannya dengan standar $\quad 0,5 \%$ McFarland atau sebanding dengan jumlah bakteri $10^{5}$ (CFU) $/ \mathrm{ml}$.

\section{HASIL DAN PEMBAHASAN METODE}

Optimasi formula sediaan gel antiseptik menggunakan metode Simplex lattice design, kemudian pada pengujian aktivitas antibakteri mengunakan metode sumuran. Formula sediaan gel antiseptik disajikan pada Tabel 1.

Tabel 1. Formulasi sediaan gel antiseptik

\begin{tabular}{lllllllll}
\hline \multirow{2}{*}{ Bahan } & \multicolumn{8}{c}{ Komposisi (gram) } \\
\cline { 2 - 9 } & R1 & R2 & R3 & R4 & R5 & R6 & R7 & R8 \\
\hline $\begin{array}{l}\text { Ekstrak Daun } \\
\text { Beluntas }\end{array}$ & 1 & 1 & 1 & 1 & 1 & 1 & 1 & 1 \\
HPMC & 4 & 3,75 & 4,5 & 4 & 3,5 & 4,5 & 3,5 & 4,25 \\
Karbopol & 1 & 1,25 & 0,5 & 1 & 1,5 & 0,5 & 1,5 & 0,75 \\
TEA & 0,25 & 0,25 & 0,25 & 0,25 & 0,25 & 0,25 & 0,25 & 0,25 \\
Gliserin & 5 & 5 & 5 & 5 & 5 & 5 & 5 & 5 \\
Na Metabisulfit & 0,1 & 0,1 & 0,1 & 0,1 & 0,1 & 0,1 & 0,1 & 0,1 \\
Aquades & Ad & Ad & Ad & Ad & Ad & Ad & Ad & Ad \\
& 100 & 100 & 100 & 100 & 100 & 100 & 100 & 100 \\
\hline
\end{tabular}

Tabel 2. Hasil uji pH, Uji day sebar, Uji Viskositas gel antiseptik

\begin{tabular}{ccccc}
\hline Run & Formula & $\mathrm{pH}$ & Daya Sebar (mm) & Viskositas (dpa.S) \\
\hline 1 & F1 & 5,8 & 41 & 800 \\
2 & F2 & 5,7 & 42 & 800 \\
3 & F3 & 6,1 & 53 & 500 \\
4 & F4 & 6,3 & 39 & 750 \\
5 & F5 & 6,1 & 48 & 600 \\
6 & F6 & 6,5 & 47 & 800 \\
7 & F7 & 6,5 & 41 & 890 \\
8 & F8 & 7,1 & 48 & 550 \\
\hline
\end{tabular}


Jurnal Insan Farmasi Indonesia, 3(2) Desember 2020 (327-336)

Muhammad Dienulloh Qasyfur Rohman

p-ISSN 2621-3184 ; e-ISSN 2621-4032

doi: $10.36387 /$ jifi.v3i2.566

Tabel 3. Hasil uji stabilitas sediaan gel antiseptik terhadap uji pH, Uji daya sebar

\begin{tabular}{cccc}
\hline Siklus & $\mathrm{pH}$ & Daya Sebar(mm) & Viskositas(dpa.S) \\
\hline 1 & 5 & 5,0 & 630 \\
2 & 5 & 5,1 & 420 \\
3 & 5 & 5,1 & 420 \\
\hline
\end{tabular}

Tabel 4. Perbandingan hasil prediksi formula optimum dengan hasil percobaan.

\begin{tabular}{ccccc}
\hline Respon & Prediksi SLD & Hasil Percobaan & Sig. (2 tailed) & Kesimpulan \\
\hline Uji pH & 6,32 & 5 & 0,081 & $\begin{array}{c}\text { Tidak berbeda } \\
\text { bermakna } \\
\text { Uji Daya Sebar (mm) }\end{array}$ tidak berbeda \\
bermakna \\
Viskositas (dpa.S) & 641,25 & 49,3 & 0,055 & $\begin{array}{c}\text { Tidak berbeda } \\
\text { bermakna }\end{array}$ \\
\hline
\end{tabular}

Tabel 5. Hasil Uji Aktivitas Antibakteri sediaan gel antiseptik ekstrak etanol daun beluntas

\begin{tabular}{cccc}
\hline Perlakuan & Zona hambat $(\mathrm{mm})$ & $\mathrm{K}(+)(\mathrm{mm})$ & $\mathrm{K}(-)(\mathrm{mm})$ \\
\hline Replikasi I & 17,2 & 28,5 & 0 \\
Replikasi II & 17,3 & 29,5 & 0 \\
Replikasi III & 18,5 & 31,8 & 0 \\
Rata-rata & 17,6 & 29,9 & 0 \\
\hline
\end{tabular}

\section{Uji homogenitas}

Pada Pengujian homogenitas didapatkan hasil tidak terdapat bulir maupun gumpalan pada sediaan $\operatorname{gel}^{(7)}$. Uji pH

Berdasarkan tabel 2, didapatkan hasil dari pengujian 8 formula yang cukup signifikan pada peningkatan konsentrasi HPMC yang digunakan. Semakin tinggi konsentrasi HPMC yang digunakan maka semakin tinggi nilai $\mathrm{pH}$ yang dihasilkan $^{(14)}$.

\section{Uji daya sebar}

Hasil yang didapatkan bahwa adanya hubungan antara daya sebar terhadap meningkatnya konsentrasi HPMC dan Karbopol yang digunakan. Semakin tinggi konsentrasi HPMC dan Karbopol yang digunakan akan menyebabkan daya sebar dari sediaan gel yang dihasilkan akan menurun. 
Jurnal Insan Farmasi Indonesia, 3(2) Desember 2020 (327-336)

Muhammad Dienulloh Qasyfur Rohman

p-ISSN 2621-3184 ; e-ISSN 2621-4032

doi: $10.36387 /$ jifi.v3i2.566

\section{uji Viskositas}

Pengujian viskositas suatu sediaan sangat berhubungan dengan kemampuan suatu sediaan untuk mengalir, dimana viskositas memiliki hubungan yang berbanding terbalik terhadap daya sebar.

\section{Uji konsistensi}

Hasil yang didapatkan sediaan yang dibuat memenuhi persyaratan pada uji konsistensi dan tetap memiliki konsistensi semi solid setelah diberikan perlakuan ${ }^{(15)}$.

\section{Penentuan formula optimum}

Formula optimum yang didapatkan pada software design expert memberikan 1 solusi formula optimum yang sesuai dengan kriteria yang diinginkan yaitu pada kombinasi HPMC 4,5\% dan Karbopol 0,5\% dengan nilai desirability sebesar $0,829^{(9)}$.

\section{Uji stabilitas sediaan gel antiseptik}

Pada uji stabilitas yang telah dilakukan sebanyak 3 siklus. Hasil pengujian 3 siklus pada formula optimum tidak didapati terjadinya perubahan warna, bau, dan bentuk.

$$
\text { Pengujian } \mathrm{pH} \text { pada formula }
$$

optimum tidak mengalami perubahan nilai $\mathrm{pH}$ yang dihasilkan maka dapat disimpulkan bahwa pada formula optimum mempunyai stabilitas yang baik serta tidak dipengaruhi oleh perubahan temperatur.

Pada uji daya sebar sediaan gel antiseptik didapatkan hasil uji daya sebar yang semakin meningkat selama proses penyimpanan pada setiap siklusnya, dimana hasil ini terjadi ketidakstabilan daya sebar gel antiseptik selama proses uji stabilitas sediaan gel.

Hasil uji konsistensi sediaan gel antiseptik pada setiap siklusnya tidak mengalami perubahan sehingga dapat disimpulkan formula optimum sediaan gel antiseptik memiliki konsistensi yang baik selama proses penyimpanan.

\section{Verifikasi formula optimum}

Pada verifikasi formula optimum didapatkan hasil bahwa tidak ada perbedaan yang bermakna antara hasil prediksi dengan hasil percobaan.

Identifikasi Bakteri Staphylococcus aureus

\section{Perwarnaan gram}


Jurnal Insan Farmasi Indonesia, 3(2) Desember 2020 (327-336)

Muhammad Dienulloh Qasyfur Rohman

p-ISSN 2621-3184 ; e-ISSN 2621-4032

doi: 10.36387/jifi.v3i2.566

Hasil pengecatan pada ditandai dengan adanya gumpalan penelitian didapatkan hasil yang sesuai dengan ciri-ciri yang ada pada bakteri Staphyloccus aureus yaitu berwarna ungu dan memiliki bentuk coccus dan bergerombol. Warna ungu yang terbentuk disebabkan oleh bakteri yang mempertahankan warna pertama yaitu kristal violet ${ }^{(16)}$.

Identifikasi pada media MSA

Media MSA merupakan media yang dapat digunakan untuk mengidentifikasi

bakteri

Staphylococcus aureus Hasil yang didapatkan positif adanya bakteri Staphylococcus aureus karena media yang digunakan berubah warna menjadi kuning.

\section{Uji katalase}

Bertujuan untuk membedakan bakteri Staphylococcus aureus dengan bakteri lainnya. Hasil positif ditandai dengan adanya gelembung yang menandakan bahwa koloni tersebut merupakan bakteri Staphylococcus. ${ }^{(12)}$.

\section{Uji Koagulase}

Uji koagulase didapatkan hasil positif bakteri Staphylococcus aureus yang yang terbentuk.

\section{Pengujian aktivitas zona hambat}

Hasil yang didapatkan pada pengujian aktivitas antibakteri dengan formula optimum didapatkan zona hambat radikal. Hal ini sesuai dengan penelitian yang telah dilakukan oleh $\mathrm{Manu}^{(17)}$ yang menyatakan bahwa ekstrak etanol daun beluntas memiliki aktivitas penghambatan terhadap bakteri Staphylococcus aureus. ${ }^{(18)}$.

kemampuan penghambatan yang dimiliki oleh ekstrak etanol daun beluntas karena pada daun beluntas memiliki senyawa flavonoid Senyawa flavonoid merupakan senyawa suatu senyawa yang mempunyai mekanisme kerja dengan cara membentuk senyawa komplek dengan dinding sel bakteri, ${ }^{(19)}$.

Analisis statistik sediaan gel antiseptik ekstrak etanol daun beluntas menggunakan independen $t$ test didapatkan hasil yang berbeda signifikan dengan nilai signifikansi < 0,05. Oleh sebab itu, dapat disimpulkan bahwa daya hambat yang dimiliki oleh sediaan gel antiseptik memiliki perbedaan yang 
Jurnal Insan Farmasi Indonesia, 3(2) Desember 2020 (327-336)

Muhammad Dienulloh Qasyfur Rohman

p-ISSN 2621-3184 ; e-ISSN 2621-4032

doi: $10.36387 /$ jifi.v3i2.566

signifikan dengan kontrol positif ciprofloxacin dalam kemampuan penghambatan terhadap bakteri Staphylococcus aureus.

\section{KESIMPULAN}

1. Pada komposisi HPMC dan Karbopol dengan konsentrasi (4,5\%:0,5\%) telah memenuhi persyaratan pada uji homogenitas, $\mathrm{pH}$, daya sebar, viskositas, konsistensi dan uji stabilitas.

2. Pada formula optimum sediaan gel antiseptik ekstrak etanol daun beluntas didapatkan zona hambat terhadap bakteri Staphylococcus aureus dengan rata-rata zona hambat sebesar 17,66 $\mathrm{mm}$ lebih kecil dibandingkan dengan kontrol positif.

\section{DAFTAR PUSTAKA}

1. Manarisip, T., Yamelan V.Y Paulina., Lolo Astuty Widya., 2019, Formulasi dan Uji Efektivitas Antibakteri Sediaan Gel Ekstrak Etanol Daun Kersen (Muntingiacalabura L.) Sebagai Antiseptik Tangan Vol 8 (3), 166.

2. Asngad, Aminah., R, Bagus, Aprilia., Novitasari., 2018, Kualitas Gel Pembersih Tangan (Handsanitizer) dari Ekstrak Batang Pisang dengan Penambahan Alkohol, Triloksan dan Gliserin yang Berbeda Dosisnya. Vol 4. No 2. Mumpuni, E., Rahayu, L., Nurrochmad, A. Toksisitas dan Antiinflamasi
Senyawa 1,5-bis(3'-etoksi-4'hidroksifenil)-1,4-pentadien-3-on, JIFI . 2015. 13(1) : 45-49.

3. Rompas, A, W, M., 2014, Pengaruh Variasi CMC-Na Sebagai Gelling Agent Terhadap Sifat Fisik dan Stabilitas Fisik Sediaan Sabun Cuci Tangan Antibakteri Ekstrak Etanol Daun Beluntas (Pluchea indica (L.) Less), Skripsi, Fakultas Farmasi Universitas Sanata Dharma, Yogyakarta.

4. Widyawati, P, S, C, H., Wijaya, P, S., Hardjosworo, dan D, Satuhi., 2013, Aktivitas Antioksidan Berbagai Fraksi dan Ekstrak Metanolik Daun Beluntas (Pluche indica Less). Agritech 32(3): 249257.

5. Murdiyani, R.A., 2013, Optimasi Kombinasi Karbopol dan HMPC (Hidroksipropil Metil Selulosa) Terhadap Efektivitas Gel Antiseptik Ekstrak Metanol Daun Kesum (Polygonumminus Huds) Dengan Metode Simplex Lattice DesigN, (Skripsi), Fakultas Kedokteran, Universitas Tanjungpura, Pontianak.

6. Ningsih, R.D., Purwati, P., Zusfahair, Z., Nurdin, A., 2019, Hand Sanitizer Ekstrak Metanol Daun Mangga Arumanis (Mangifera indica L.) Vol.15(1), 13-14.

7. Rodhiya, A, N., 2016, Formulasi Sediaan Gel Hand sanitizer Ekstrak Etanol Daun Ashitaba (Angelica keiskei) Dengan Variasi Basis Carbopol, 940 dan CMC-Na.

8. Tambunan, S., Sulaiman, Saifullah, Nanda, Teuku., 2018, Formulasi Gel Minyak Atsri Sereh 
Jurnal Insan Farmasi Indonesia, 3(2) Desember 2020 (327-336)

Muhammad Dienulloh Qasyfur Rohman

p-ISSN 2621-3184 ; e-ISSN 2621-4032

doi: $10.36387 /$ jifi.v3i2.566

dengan Basis HPMC dan Karbopol Vol 14 (2), 89.

9. Syaiful, Dewi, Sartika., 2016, Formulasi dan Uji Stabilitas Gel Ekstrak Daun Kemangi (Ocimum sanctum L.) Sebagai Sediaan Hand Sanitizer, (Skripsi). Fakultas Kedokteran dan Ilmu Kesehatan, Universitas Islam Negeri Alaudin Makasar.

10. Waluyo, L., 2010. Teknik Metode Dasar Mikrobiologi. UMM Press. Malang.

11. Toelle, Neliyani, Novianti., Lenda, Viktor., 2014, Identifikasi dan Karakteristik Staphylococcus Sp. dan Streptococcus Sp. Dari Infeksi Ovarium Pada Ayam Petelur Komersial, Vol. 1, No. 7,32-37.

12. Iman, E.R.S., Ratih, R., Hasutji, E.N., Suryanie., Wiwiek, $\mathrm{T}$ dan Sri, C. 2011. Buku Ajar Mikrobiologi Veteriner I. Airlangga University Press: Surabaya.

13. Ardana, Mirhansyah., Aeyn, Vebry., Ibrahim A., 2015, Formulasi dan Optimasi Basis Gel HPMC (HYDROXY PROPYL METHYL CELLULOSE) Dengan Berbagai Variasi Konsentrasi. Vol 3. No 2 .

14. Djajadisastra, J., Mun'im, A. and NP, D., 2009, Formulasi Gel Topikal Dari Ekstrak Nerii Folium Dalam Sediaan Anti Jerawat, Jurnal Farmasi Indonesia, 4(4), 210-216.

15. Dewi, K.A., 2013, Isolasi, Identifikasi dan Uji Sensitivitas Staphylococcus aureus terhadap Amoxicillin dari Sampel Susu Kambing Peranakan Ettawa (PE) Penderita Mastitis di Wilayah
Girimulyo, Kulonprogo, Yogyakarta, Jurnal Sain Veteriner 31:2. 140-141.

16. Ratna, Radjani, Sakti, M., 2013, Aktivitas Antibakteri Ekstrak Etanol Daun Beluntas (Pluchea indica L.) Terhadap Staphylococcus aureus, Bacillus subtilis Dan Pseudomonas aeruginosa, Vol. 2 No.1 (2013).

17. Kementrian Kesehatan Republik Indonesia. Riset Kesehatan Dasar. Kementrian Kesehatan RI. Jakarta; 2010.

18. Rendra, A, 2011, Uji Potensi Ekstrak Etanol Daun Beluntas (Pluchea indica) sebagai Antimikroba terhadap Bakteri Escheria coli secara in vitro. (tugas akhir). Fakultas Kedokteran Universitas Brawijaya

19. Saifudin, Aziz. 2014. Senyawa Alam Metabolit Sekunder Teori, Konsep, dan Teknik Pemurnian.Yogyakarta:Deepublis $\mathrm{h}$ 